\title{
Expressive Writing untuk Keterampilan Mengelola Emosi Marah Siswa
}

\author{
Nurhayani Maudi ${ }^{1}$, Triyono ${ }^{1}$, Dany M. Handirini ${ }^{1}$ \\ ${ }^{1}$ Bimbingan Konseling-Universitas Negeri Malang
}

\begin{tabular}{l}
\hline \hline INFO ARTIKEL \\
\hline Riwayat Artikel: \\
Diterima: 05-07-2019 \\
Disetujui: $12-12-2019$ \\
\hline
\end{tabular}

\section{Kata kunci:}

training guide; managing angry emotions; expressive writing; panduan pelatihan; mengelola emosi marah; expressive writing;

\begin{abstract}
This study aims to develop a guide to training anger management skills using the expressive writing method for junior high school students. The method used in this study is a research and development model. The trial subjects in this study consisted of instructional media experts, guidance and counseling expertsand prospective users or school counselors. the instruments used are in the form of expert assessment instruments and prospective user assessment instruments. The results of the trial consisted of quantitative data and qualitative data. Data analysis techniques in this research and development are descriptive analysis techniques. The results of the assessment of learning media experts, guidance and counseling experts andprospective users indicate that the developed products are acceptable and feasible to use to improve anger management skills by using expressive writing methods for junior high school students.
\end{abstract}

ABSTRAK

\begin{abstract}
Abstrak: Penelitian ini bertujuan untuk mengembangkan panduan pelatihan keterampilan mengelola emosi marah dengan menggunakan metode expressive writing untuk siswa Sekolah Menengah Pertama. Metode yang digunakan dalam penelitian ini adalah model penelitian dan pengembangan. Subjek uji coba pada penelitian ini terdiri dari ahlimedia pembelajaran, ahli bimbingan dan konseling serta calon pengguna atau konselor sekolah. Instrumen yang digunakan berupa berupa instrumen penilaian ahli dan instrumen penilaian calon pengguna. Hasil uji coba terdiri dari data kuantitatif dan data kualitatif. Teknik analisis data dalam penelitian dan pengembangan ini adalah teknik analisis deskriptif. Adapun hasil dari penilaian ahli media pembelajaran, ahli bimbingan dan konseling, dan calon pengguna menunjukkan bahwa produk yang dikembangkan dapat diterima dan layak digunakan untuk meningkatkan keterampilan mengelola emosi marah dengan menggunakan metode expressive writing bagi siswa SMP.
\end{abstract}

\section{Alamat Korespondensi:}

Nurhayani Maudi

Bimbingan Konseling

Universitas Nergeri Malang

Jalan Semarang 5 Malang

E-mail: nurhayanimaudi@yahoo.com

Marah adalah salah satu emosi yang paling kuat jika mempertimbangkan dampak yang mendalam pada hubugan sosial serta efek pada orang yang mengalami emosi ini (Lazarus, 1991). Dalam hubungan sosial, dampak emosi marah yang tidak dapat dikendalikan akan memicu munculnya tindakan kekerasan. Kekerasan merupakan manifestasi dari kemarahan yang tidak bisa dikendalikan (Ekman, 2003). Individu yang kerap melakukan tindakan kekerasan cenderung akan dikucilkan dari lingkungan pergaulan. Sementara itu marah juga dapat berdampak bagi diri sendiri. sebagian orang bersalah atau malu dengan emosi marah yang telah ditampakkannya (Ekman, 2003). Pada saat seseorang sedang marah bukan berarti harus mengekspresikannya secara agresif dan perilaku kekerasan lainnya. marah merupakan emosi yang bersumber dari internal dan eksternal sebagai reaksi yang wajar untuk keberlangsungan hidup (Bhave \& Saini, 2009). Banyaknya tindakan kekerasan yang dilakukan oleh remaja menunjukkan bahwa mereka kurang mampu mengelola emosi marah yang dirasakannya. Ketidakmampuan mengelola emosi marah yang dirasakan dapat menimbulkan berbagai permasalahan yang dapat merugikan diri sendiri maupun orang lain. kemampuan mengelola emosi merupakan hal yang harus dimiliki oleh remaja. Kemampuan mengelola emosi merupakan salah satu kemampuan utama dalam kecerdasan emosional sebab EQ menyumbang kira-kira 80\% bagi kesusksesan hidup individu (Goleman, 2005).

Ketidakmampuan siswa mengendalikan emosinya disebabkan karena kurangnya bimbingan dari guru. Guru BK sebagai pihak yang membantu siswa mencapai perkembangan yang optimal seharusnya bertindak cepat dalam membantu siswa untuk belajar mengelola emosi marahnya. Hal ini sejalan dengan konteks tugas konselor atau Guru BK sesuai dengan Standar Kompetensi Kemandirian Peserta Didik pada aspek kematangan emosi untuk siswa sekolah menengah pertama (Departemen Pendidikan Nasional, 2008). Berdasarkan hasil wawancara dengan salah satu Guru BK SMP di kota Kendari, selama ini untuk menangani kasus kekerasan seperti perkelahian hanya diberikan layanan individual dalam bentuk nasehat agar tidak mengulangi perbuatannya. Guru BK tidak pernah memberikan pelatihan bagaimana siswa dapat mengelola marahnya dengan baik. 
Tujuan latihan mengatasi kemarahan bukan tentang memahami mengapa kemarahan terjadi dalam beberapa situasi, tetapi untuk mengidentifikasi situasi di mana anak-anak perlu mengendalikannya. Dalam penelitian yang dilakukan terhadap konseptualisasi dan representasi kemarahan dalam program berbasis manual untuk pelatihan sosial dan emosional yang digunakan dalam kelompok prasekolah. Hasilnya, kemarahan sangat disadari dalam program-program tersebut, disoroti sebagai emosi destruktif yang perlu dikendalikan sehingga anak-anak diharapkan dapat mengatur pengalaman pribadi mereka. Kekhawatiran yang disebabkan oleh perilaku kekerasan telah menyebabkan banyak sekolah untuk menerapkan manajemen kemarahan dan program berbasis kontrol impuls lainnya untuk siswa yang berisiko dalam upaya untuk mencegah banyak insiden ini. penelitiannya menunjukkan efek intervensi kecil hingga sedang dalam mengurangi emosi dan perilaku negatif anak-anak termasuk kemarahan, agresi, dan hilangnya kontrol diri (Bartholdsson, 2014); Candelaria, Fedewa, \& Ahn, 2012); (Felce et al., 2015).

Dalam mengelola emosi marah faktor jenis kelamin, etnis dan dukungan orangtua memberikan pengaruh yang penting. menemukan perbedaan etnis gender dalam pengaturan amarah dimana perempuan kulit putih melaporkan tingkat kemarahan yang lebih tinggi daripada gadis kulit hitam, dan gadis kulit hitam melaporkan tingkat kemarahan yang lebih tinggi daripada perempuan kulit putih (Perry-Parrish et al., 2017). Dukungan orangtua secara positif terkait dengan perilaku prososial baik langsung dan tidak langsung melalui regulasi kemarahan (Houltberg, Sheffield Morris, Cui, Henry, \& Criss, 2016). Penelitian menggunakan model mediasi menunjukkan bahwa penindasan kemarahan terlibat dalam hubungan antara dimensi kelekatan dan permusuhan, tetapi bukan agresi fisik. Hal Ini mendukung gagasan bahwa penindasan mungkin berguna dalam mengurangi ekspresi kemarahan eksternal tetapi tidak dapat meringankan yang terkait dengan kognisi internal (Brodie, Goodall, Darling, \& McVittie, 2019).

Salah satu metode yang dapat digunakan untuk meningkatkan keterampilan mengelola emosi marah siswa adalah dengan metode expressive writing. Expressive writing merupakan metode menulis ekspresif untuk mengungkapkan pengalaman emosional yang dapat memperbaiki fisik, pikiran, dan perilaku ke arah yang lebih baik. Teknik ini dikembangkan oleh Pennebeker dan efektif dalam mengurangi emosi negatif pada individu. Teknik ini merupakan salah satu metode katarsis dimana konseli melepaskan emosi melalui tulisan dan dapat meningkatkan pengalaman baru pada diri konseli. Expressive writing lebih menekankan pada pengungkapan pikiran atau perasaan dengan menulis yang akan membuat individu melepaskan perasaanperasaan yang bergejolak dalam hati dan mengubah cara individu dalam menghadapi emosi marah. Melalui metode Expressive writing emosi marah dapat disalurkan secara konstruktif.

Expressive writing dapat digunakan sebagai alat terapi untuk menanggani trauma dan dalam pengaturan kejiwaan. Hal ini sejalan dengan penelitian yang dilakukan oleh (Koopman et al., 2005); (Frattaroli, Thomas, \& Lyubomirsky, 2011), (Meston, Lorenz, \& Stephenson, 2013), (Randler et al., 2015) yang menyimpulkan bahwa expressive writing efektif untuk mengurangi gejala kecemasan, depresi, gangguan stress pasca trauma pada situasi individu yang memiliki kecenderungan ruminative, kekerasan seksual dan menghadapi ujian. Expressive writing juga dapat digunakan pada konseli yang tidak dapat mengekspresikan emosinya. (Niles, Haltom, Mulvenna, Lieberman, \& Stanton, 2014) menyatakan bahwa expressive writing tentang peristiwa yang menimbulkan stres dapat dikontraindikasikan untuk individu yang biasanya tidak dapat mengekspresikan emosi. Expressive writing memengaruhi perubahan kognitif, emosional, perilaku, dan situasional (Schutte, Searle, Meade, \& Dark, 2012).

Penelitian mengenai peningkatan keterampilan mengelola marah telah dilakukan oleh (Nurvita, 2015) dengan menggunakan strategi emotional literacy dan Focus Group Discussion. Metode ini efektif untuk meningkatkan keterampilan mengelola marah di SMP. Kemudian penelitian yang dilakukan oleh (Wahyuni, 2012), menggunakan pendekatan Cognitive Behavior Modification (CBM), dan hasil dari penelitian ini sesuai dengan tujuan penelitian yaitu peningkatan keterampilan mengelola marah. Berdasarkan ulasan dari berbagai masalah, kami melaksanakan penelitian dan pengembangan pelatihan mengelola marah dengan Expressive writing.

\section{METODE}

Metode yang digunakan dalam penelitian ini mengadaptasi model penelitian pengembangan dari model Borg \& Gall. Pemilihan pengembangan yang diadaptasi dari model Borg and Gall berdasarkan pertimbangan peneliti, dalam penelitian dan pengembangan ini peneliti melakukan modifikasi prosedur pada model penelitian dan pengembangan yang disesuaikan dengan kebutuhan dan kondisi dalam proses penelitian dan pengembangan yang dilakukan (Borg \& Gall, 1983). Dalam penelitian dan pengembangan yang bertujuan untuk menghasilkan produk panduan pelatihan mengelola emosi marah dengan expressive writing untuk Siswa, peneliti menggunakan lima langkah/tahapan penelitian dan pengembangan model Borg \& Gall, yakni (1) research and information collecting (penelitian dan pengumpulan informasi awal); (2) planning (perencanaan); (3) develop preliminary from of product (pengembangan format produk awal); (4) preliminary field testing (uji coba produk awal); (5) main product revision (revisi produk).

Setelah draf produk selesai dibuat, kemudian dilakukan uji coba ahli yang menghasilkan skala penilaian angka dan penilaian secara deskriptif. Uji coba ahli terdiri ahli media pembelajaran dan ahli Bimbingan dan Konseling. Hasil dari penialain uji ahli tesebut dijadikan sebagai dasar perbaikan produk. setelah diperbaiki, produk diuji oleh calon pengguna yaitu konselr SMP yang menghasilkan penilaian skala angka dan penilaian deskriptif. hasil penilaian dari konselor digunakan sebagai dasar pertimbangan untuk menyempurnakan produk. 
Data yang diperoleh dari uji coba penelitian berupa skala angka dan penilaian deskriptif berupa saran dan komentar terkait produk. Teknik analisis data yang digunakan terhadap hasil uji ahli menggunakan teknik analisis data deskriptif dan calon pengguna menggunakan teknik Percentage of Agreement untuk aspek kegunaan, kelayakan, ketepatan, dan kepatutan (Gridnell, 1988).

\section{HASIL}

Produk yang dihasilkan dalam penelitian dan pengembangan ini adalah panduan pelatihan keterampilan mengelola emosi marah dengan expressive writing. Sistematika panduan terdiri dari tiga bagian, yaitu (1) pendahuluan, (2) petunjuk umum, dan (3) prosedur pelatihan. Keseluruhan prduk pengembangan panduan keterampilan mengelola emosi marah dengan expressive writing berupa prototype diuji cobakan. Uji coba pengembangan panduan pelatihan keterampilan mengelola emosi marah bagi siswa Sekolah Menengah Pertama ini dilaksanakan dalam dua tahapan, yaitu (1) uji ahli bertujuan untuk menguji akseptabilitas panduan pelatihan keterampilan mengelola emosi marah dari segi isinya. Hasil yang diperoleh dari uji ahli digunakan untuk melakukan revisi terhadap prduk pengembangan serta mendapatkan masukan dan kekurangan yang ada dalam rancangan panduan sebelum dilaksanakan pada calon pengguna dan (2) uji pengguna yaitu konselor sekolah atau guru Bimbingan dan Konseling yang bertujuan untuk mengetahui akseptabilitas panduan pelatihan keterampilan mengelola emosi marah. Uji calon pengguna atau kelompok kecil ini terdiri dari tiga orang Guru BK. Hasil penilaian oleh ahli media pembelajaran terhadap produk pelatihan mengelola emosi marah dengan metode expressive writing dijabarkan sebagaimana pada tabel 1.

\section{Tabel 1. Data Hasil Penilaian Ahli Media Pembelajaran Aspek Kemenarikan}

\begin{tabular}{|c|c|c|}
\hline No. & Butir Penilaian & Ahli Media Pembelajaran \\
\hline \multicolumn{3}{|c|}{$\begin{array}{l}\text { Indikator I: Kegrafisan } \\
\end{array}$} \\
\hline 1. & $\begin{array}{l}\text { Bagaimanakah tingkat kemenarikan sampul buku } \\
\text { panduan pelatihan mengelola emosi marah? }\end{array}$ & 3 \\
\hline 2. & $\begin{array}{l}\text { Bagaimanakah tingkat kemenarikan warna sampul buku } \\
\text { panduan pelatihan mengelola emosi marah? }\end{array}$ & 4 \\
\hline 3. & $\begin{array}{l}\text { Bagaimanakah tingkat kemenarikan desain sampul buku } \\
\text { panduan pelatihan mengelola emosi marah? }\end{array}$ & 4 \\
\hline 4. & $\begin{array}{l}\text { Bagaimanakah tingkat kemenarikan desain halaman isi } \\
\text { buku panduan pelatihan mengelola emosi marah. }\end{array}$ & 4 \\
\hline \multicolumn{3}{|c|}{ Indikator II: Kebahasaan } \\
\hline 5. & $\begin{array}{l}\text { Bagaimanakah tingkat kemenarikan jenis huruf dan } \\
\text { struktur penulisan pada buku panduan pelatihan } \\
\text { keterampilan mengelola emosi? }\end{array}$ & 4 \\
\hline 6. & $\begin{array}{l}\text { Bagaimanakah tingkat kemenarikan gaya penulisan buku } \\
\text { panduan pelatihan mengelola emosi marah. }\end{array}$ & 4 \\
\hline 7. & $\begin{array}{l}\text { Bagaimanakah tingkat kemenarikan struktur penulisan } \\
\text { pada buku panduan pelatihan keterampilan mengelola } \\
\text { emosi? }\end{array}$ & 4 \\
\hline
\end{tabular}

Berdasarkan keseluruhan hasil penilaian oleh ahli media pembelajaran diketahui terdapat hasil penilaian 4 dan 3 , tidak terdapat skor rendah untuk setiap butir penilaian. Jadi, dapat dinterpretasikan bahwa penilaian ahli media pembelajaran terhadap panduan pelatihan keterampilan mengelola emosi marah menunjukkan kriteria diterima/akseptabel dari segi kemenarikannya. Analisis dari hasil penilaian oleh ahli BK dilakukan untuk mengungkapakseptabilitas/keberterimaan produk yang telah dikembangkan berdasarkan kriteria kegunaan, kelayakan, ketepatan, dan kepatutan yang diuraikan dalam bentuk data sebagaimana pada tabel 2 .

Berdasarkan keseluruhan hasil penilaian dari dua ahli BK untuk setiap aspek baik aspek kegunaan, kelayakan, ketepatan, dan kepatutan diketahui bahwa masing-masing ahli memberikan nilai 3 dan 4 serta nilai 2 untuk satu butir pertanyaan. Dengan demikian, dapat dinterpretasikan bahwa penilaian ahli Bimbingan dan Konseling terhadap panduan keterampilan mengelola emosi marah untuk siswa SMP menunjukkan kriteria diterima/akseptabel dari segi ketepatan, walaupun terdapat penilaian yang rendah pada satu butir penilaian yang kemudian akan ditindaklanjuti dengan perbaikan berdasarkan masukan dan kritrik dari ahli Bimbingan dan Konseling tersebut. Penilaian pada tahap selanjutnya diberikan kepada Guru BK sebagai calon pengguna panduan pelatihan yang dikembangkan. Analisis dari hasil penilaian oleh guru BK dilakukan untuk mengungkap akseptabilitas/keberterimaan produk yang telah dikembangkan berdasarkan kriteria kegunaan, kelayakan, dan ketepatan yang diuraikan dalam bentuk data sebagaimana pada tabel 3 . 
Tabel 2. Data Hasil Penilaian Ahli Bimbingan dan Konseling

\begin{tabular}{|c|c|c|c|}
\hline \multirow{2}{*}{ No. } & \multirow{2}{*}{ Aspek Penilaian } & \multicolumn{2}{|c|}{ Ahli BK } \\
\hline & & Ahli 1 & Ahli 2 \\
\hline 1. & $\begin{array}{l}\text { Bagaimanakah tingkat kebermanfaatan panduan keterampilan } \\
\text { mengelola emosi marah bagi Guru BK? }\end{array}$ & 4 & 4 \\
\hline 2. & $\begin{array}{l}\text { Bagaimanakah tingkat kebermanfaatan panduan keterampilan } \\
\text { mengelola emosi marah bagi Siswa? }\end{array}$ & 4 & 3 \\
\hline 3. & $\begin{array}{l}\text { Apakah topik pelatihan keterampilan mengelola emosi marah } \\
\text { dengan expressive writing sesuai dengan kebutuhan siswa? }\end{array}$ & 3 & 4 \\
\hline 4. & $\begin{array}{l}\text { Apakah panduan keterampilan mengelola emosi marah } \\
\text { membantu Guru BK meningkatkan pemahaman siswa mengenai } \\
\text { emosi dirinya? }\end{array}$ & 3 & 4 \\
\hline \multicolumn{4}{|c|}{$\begin{array}{ll}\text { Aspek Kelayakan } \\
\end{array}$} \\
\hline 1. & $\begin{array}{l}\text { Seberapa praktis Expressive Writing digunakan dalam pelatihan } \\
\text { membantu siswa meningkatkan keterampilan mengelola emosi } \\
\text { marah? }\end{array}$ & 3 & 3 \\
\hline 2. & $\begin{array}{l}\text { Apakah waktu yang dibutuhkan cukup efisien untuk } \\
\text { melaksanakan pelatihan keterampilan mengelola emosi marah di } \\
\text { sekolah? }\end{array}$ & 3 & 3 \\
\hline 3. & $\begin{array}{l}\text { Apakah alokasi waktu pelayanan BK di sekolah cukup untuk } \\
\text { terlaksananya pelatihan keterampilan mengelola emosi marah } \\
\text { dengan expressive writing? }\end{array}$ & 3 & 3 \\
\hline \multicolumn{4}{|c|}{ Aspek Ketepatan } \\
\hline 1. & $\begin{array}{l}\text { Apakah rumusan tujuan pada setiap komponen materi pelatihan } \\
\text { keterampilan mengelola emosi operasional? }\end{array}$ & 3 & 2 \\
\hline 2. & $\begin{array}{l}\text { Apakah rancangan tugas-tugas individu dalam panduan ini sesuai } \\
\text { untuk meningkatkan pemahaman siswa tentang konsep dasar } \\
\text { mengelola emosi diri? }\end{array}$ & 4 & 3 \\
\hline \multicolumn{4}{|c|}{ Aspek Kepatutan } \\
\hline 1. & $\begin{array}{l}\text { Apakah Guru BK yang melaksanakan pelatihan perlu menguasai } \\
\text { materi pelatihan keterampilan mengelola emosi marah? }\end{array}$ & 4 & 4 \\
\hline 2. & $\begin{array}{l}\text { Apakah Guru BK yang melaksanakan pelatihan keterampilan } \\
\text { mengelola emosi marah ini perlu menjunjung tinggi kode etik } \\
\text { profesi Guru BK? }\end{array}$ & 4 & 4 \\
\hline
\end{tabular}

Tabel 3. Data Hasil Penilaian Calon Pengguna

No. $\quad$ Aspek Penilaian

\begin{tabular}{ccccc}
\multicolumn{2}{c}{ Calon Pengguna } & \multicolumn{2}{c}{$\begin{array}{c}\text { Relevansi } \\
\text { Kesepakatan }\end{array}$} \\
\hline KO 1 & KO2 & KO3 & $(\%)$ & Kategori \\
\hline 4 & 4 & 4 & $100 \%$ & Tinggi \\
\hline 3 & 3 & 4 & $66,7 \%$ & Sedang \\
\hline 4 & 4 & 3 & $66,7 \%$ & Sedang \\
\hline 4 & 3 & 4 & $66,7 \%$ & Sedang \\
\hline 4 & 4 & 4 & $100 \%$ & Tinggi
\end{tabular}

5. Apakah panduan pelatihan mengelola emosi marah dapat membant
mencapai tujuan penelitian yaitu terhindar dari perilaku kekerasan?

\section{Aspek Kelayakan}

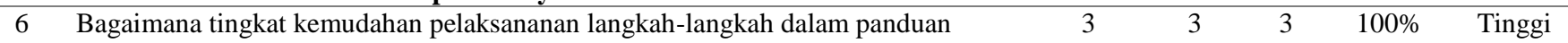
pelatihan Keterampilan mengelola emosi marah

7 Bagaimana tingkat efisiensi jumlah tenaga yang diperlukan untuk melaksanakan pelatihan keterampilan mengelola emosi marah seperti yang dirancang dalam buku panduan?

8 Bagiamana tingkat efisiensi waktu yang diperlukan untuk melaksanakan pelatihan keterampilan mengelola emosi marah seperti yang dirancang dalam buku panduan pelatihan? 
Tabel 3. Data Hasil Penilaian Calon Pengguna (Lanjutan)

\begin{tabular}{|c|c|c|c|c|c|c|}
\hline \multicolumn{7}{|c|}{ Aspek Ketepatan } \\
\hline 9 & $\begin{array}{l}\text { Seberapa tepatkah langkah-langkah pelatihan mengelola emosi marah apabila } \\
\text { diterapkan pada siswa? }\end{array}$ & 3 & 4 & 4 & $66,7 \%$ & Sedang \\
\hline 10 & $\begin{array}{l}\text { Seberapa tepatkah prosedur pelatihan apabila diterapkan pada siswa untuk } \\
\text { meningkatkan pengelolaan emosi marah? }\end{array}$ & 3 & 4 & 4 & $100 \%$ & Tinggi \\
\hline
\end{tabular}

\section{PEMBAHASAN \\ Hasil Uji Ahli Media Pembelajaran}

Uji coba yang dilakukan pada ahli media pembelajaran terdiri dari satu orang subjek. Penetapan subjek tersebut didasarkan pada kriteria-kriteria yang sudah ditetapkan oleh peneliti sehingga subjek ahli media pembelajaran dalam penelitian ini representatif untuk dijadikan sebagai ahli yang memberikan penilaian terhadap produk penelitian yang dikembangkan. Adapun hasil penilaian ahli media pembelajaran terhadap panduan pelatihan keterampilan mengelola emosi marah menunjukkan kriteria diterima/akseptabel dari segi kemenarikannya. Selanjutnya, ahli media memberikan beberapa cacatan, mauskan dan saran perbaikan berupa (1) secara umum buku panduan pelatihan keterampilan mengelola emosi marah dengan expressive writing cukup bagus, (2) optimalisasi pada penataan susunan cover, inner cover, dan desain visual cover, (3) resumsi gambar dipertajam dan lebih representatif, (4) ukuran font pada judul panduan lebih diperbesar, (5) memberikan halaman judul pada setiap halaman. Berdasarkan masukan yang diberikan dari uji media pembelajaran tersebut maka diadakan perbaikan pada buku panduan pelatihan yang dikembangkan.

\section{Hasil Uji Ahli Bimbingan dan Konseling}

Uji ahli bimbingan dan konseling terdiri dari dua ahli. hasil penilaian dari dua ahli bimbingan dan konseling baik secara kuantitaif dan secara deskriptif terhadap produk yang dikembangkan menunjukkan bahwa panduan pelatihan keterampilan mengelola emosi marah ditinjau dari segi kegunaan ahli menilai panduan pelatihan yang dikembangkan berguna untuk diterapkan bagi siswa, dari segi ketepatan ahli menilai tepat, keterlaksanaan ahli menilai layak untuk dilaksanakan, dari segi kepatutan ahli menilai patut untuk dikembangkan lebih lanjut.

Ahli pertama memberikan beberapa saran perbaikan untuk pengembangan produk penelitian berupa (1) rumusan tujuan setiap pertemuan hendaknya spesifik dan terkait dengan kemampuan mengelola emosi marah (2) petunjuk pelaksanaan pelatihan pada panduan lebih disistematiskan lagi, dan (3) terdapat beberapa butir pada skala yang belum mengukur aspek keterampilan mengelola emosi marah pada siswa.

Ahli kedua memberikan beberapa saran perbaikan berupa (1) rumusan tujuan dari setiap pertemuan sebaiknya dipecah menjadi tujuan khusus sehingga mudah dalam merumuskan tujuan secara operasional. Tujuan khusus sebaiknya mencakup aspek kognitif, afektif, dan psikomotorik (2) sebaiknya dari pertemuan satu ke pertemuan selanjutnya siswa diberikan penugasan untuk menuliskan situasi yang dihadapinya dan bagaimana penyikapannya. Hal ini bertujuan untuk meningkatkan kemampuan menulis ekspresif siswa terkait apa yang dirasakannya. Penugasan dilaporkan pada pertemuan selanjutnya, peneliti perlu membuat format penugasan dan laporannya. Berdasarkan saran dan masukan dari uji ahli bimbingan dan konseling, maka akan dilakukan perbaikan pada buku panduan pelatihan yang dikembangkan. Perbaikan terutama pada perumusan tujuan pada setiap pertemuan agar lebih jelas dan spesifik.

\section{Hasil Uji Calon Pengguna}

Uji calon pengguna diberikan kepada tiga orang konselor di salah satu SMP di kota Kendari. Dari hasil penilaian masingmasing calon pengguna menunjukkan bahwa secara umum panduan keterampilan mengelola emosi marah yang dikembangkan ditinjau dari aspek ketepatan konselor menilai tepat, keterlaksanaan konselor menilai layak, dan kegunaan konselor menilai berguna sehingga panduan dapat dikembangkan lebih lanjut dan digunakan sebagai acuan dalam memberikan layanan bimbingan dan konseling di sekolah.

Pada dasarnya panduan ini dikembangkan untuk membantu siswa Sekolah Menengah Pertama mencapai kemandirian secara emosional. Hal ini sejalan dengan Standar Kompetensi Kemandirian Peserta Didik (SKKPD). Adapun aspek perkembangan kematangan emosi untuk siswa SMP meliputi mengenal cara-cara mengekspresikan perasaan secara wajar, memahami keragaman ekspresi perasaan diri dan orang lain serta mengekspresikan perasaan atas dasar pertimbangan kontekstual (Departemen Pendidikan Nasional, 2008). Pada dasarnya tugas perkembangan remaja adalah mencapai kemandirian emosional, dimana remaja harus mampu menyalurkan emosinya dengan tepat. Emosi marah yang dapat dikelola dengan bagi akan disalurkan secara positif sehingga memberikan dampak yang baik bagi diri sendiri dan juga orang lain. Keterampilan mengelola emosi marah berperan sangat penting bagi diri konseli. Ketidakmampuan mengelola emosi merupakan gambaran adanya emosi-emosi yang tidak terkendali dan mencerminkan adanya ketidakseimbangan emosi konseli (Goleman, 2005). 


\section{SIMPULAN}

Berdasarkan hasil kajian produk pengembangan dalam penelitian yang telah dilakukan, maka diperoleh simpulan sebagai berikut. Pertama, panduan pelatihan yang dikembangkan telah memenuhi akseptabilitas ditinjau dari aspek ketepatan, aspek kegunaan, aspek kelayakan, dan aspek kepatutan. Kedua, pelatihan keterampilan mengelola emosi marah dengan expressive writing untuk siswa SMP dapat diterima dan layak untuk diimplementasikan padas siswa. Ketiga, panduan pelatihan keterampilan mengelola emosi marah yang dihasilkan dalam penelitian ini berfungsi layanan dasar yang bersifat prefentive- developmental pada ranah pribadi-sosial. Keempat, penelitian ini hanya dalam melaksanakan tahap revisi produk dari hasil uji ahli dan calon pengguna. Untuk itu perlu dilakukan tahap tindak lanjut untuk peneliti selanjutnya dapat dengan melakukan penelitian pada kelompok terbatas. Kelima, subjek uji calon pengguna hanya menggunakan satu sekolah saja. Untuk peneliti selanjutnya dapat menambahkan subjek uji pengguna di beberapa sekolah dengan karakteristik yang berbeda, agar diketahui seberapa akseptabel produk jika diujikan pada sekolah dengan karakteristik yang berbeda.

\section{DAFTAR RUJUKAN}

Bartholdsson, Å. (2014). Narrating Anger: Conceptualisations and Representations of Children's Anger in Programmes for Social and Emotional Learning. Power and Education, 6(3), 295-306. https://doi.org/10.2304/power.2014.6.3.295

Bhave, S., \& Saini, S. (2009). Anger Management. New Delhi: Sage Publication India Pvt.

Borg, W., \& Gall, M. (1983). Educational Research Third Editon. New York: Longman Inc.

Brodie, Z. P., Goodall, K., Darling, S., \& McVittie, C. (2019). Attachment Insecurity and Dispositional Aggression: The Mediating Role of Maladaptive Anger Regulation. Journal of Social and Personal Relationships, 36(6), 1831-1852. https://doi.org/10.1177/0265407518772937

Candelaria, A. M., Fedewa, A. L., \& Ahn, S. (2012). The Effects of Anger Management on Children's Social and Emotional Outcomes: A Meta-Analysis. School Psychology International, 33(6), 596-614. https://doi.org/10.1177/0143034312454360

Departemen Pendidikan Nasional. (2008). Penataan Pendidikan Profesional Konselor dan Layanan Bimbingan dan Konseling dalam Jalur Pendidikan Formal. Jakarta.

Ekman, P. (2003). Emotion Revealed: Recognizing Faces and Feelings to Improve Communication and Emotional Life. New York: Henry Holt Aad Company.

Felce, D., Cohen, D., Willner, P., Rose, J., Kroese, B., Rose, N., ... Hood, K. (2015). Cognitive Behavioural Anger Management Intervention for People with Intellectual Disabilities: Costs of Intervention and Impact on Health and Social Care Resource Use. Journal of Intellectual Disability Research, 59(1), 68-81. https://doi.org/10.1111/jir.12112

Frattaroli, J., Thomas, M., \& Lyubomirsky, S. (2011). Opening Up in the Classroom: Effects of Expressive Writing on Graduate School Entrance Exam Performance. Emotion, 11(3), 691-696. https://doi.org/10.1037/a0022946

Goleman, D. (2005). Emotional Intelligence: Kecerdasan Emosional, mengapa EI lebih penting daripada IQ. Jakarta: Gramedia Pustaka Utama.

Gridnell, J. M. (1988). Social Work Research and Evaluation-Third Edition. Illionis: F.E Peacock Publishers, Inc.

Houltberg, B. J., Sheffield Morris, A., Cui, L., Henry, C. S., \& Criss, M. M. (2016). The Role of Youth Anger in Explaining Links Between Parenting and Early Adolescent Prosocial and Antisocial Behavior. Journal of Early Adolescence, 36(3), 297-318. https://doi.org/10.1177/0272431614562834

Koopman, C., Ismailji, T., Holmes, D., Classen, C. C., Palesh, O., \& Wales, T. (2005). The Effects of Expressive Writing on Pain, Depression and Posttraumatic Stress Disorder Symptoms in Survivors of Intimate Partner Violence. Journal of Health Psychology, 10(2), 211-221. https://doi.org/10.1177/1359105305049769

Lazarus, R. S. (1991). Emotion and Adaptation. New York: Oxford University Press.

Meston, C. M., Lorenz, T. A., \& Stephenson, K. R. (2013). Effects of Expressive Writing on Sexual Dysfunction, Depression, and PTSD in Women with a History of Childhood Sexual Abuse: Results from a Randomized Clinical Trial. Journal of Sexual Medicine, 10(9), 2177-2189. https://doi.org/10.1111/jsm.12247

Niles, A. N., Haltom, K. E. B., Mulvenna, C. M., Lieberman, M. D., \& Stanton, A. L. (2014). Randomized controlled trial of Expressive Writing for Psychological and Physical Health: The Moderating Role of Emotional Expressivity. Anxiety, Stress and Coping, 27(1), 1-17. https://doi.org/10.1080/10615806.2013.802308

Nurvita, D. N. (2015). Perbandingan Keterampilan Mengelola Marah Siswa SMP yang Diintervensi dengan Strategi Emotional Literacy dan Focus Group Discussion. Tesis tidak diterbitkan. Universitas Negeri Malang, Malang.

Perry-Parrish, C., Webb, L., Zeman, J., Spencer, S., Malone, C., Borowski, S., .. Ostrander, R. (2017). Anger Regulation and Social Acceptance in Early Adolescence: Associations With Gender and Ethnicity. Journal of Early Adolescence, 37(4), 475-501. https://doi.org/10.1177/0272431615611255

Randler, C., Wüst-Ackermann, P., im Kampe, V. O., Meyer-Ahrens, I. H., Tempel, B. J., \& Vollmer, C. (2015). Effects of Expressive Writing Effects on Disgust and Anxiety in a Subsequent Dissection. Research in Science Education, 45(5), 647-661. https://doi.org/10.1007/s11165-014-9442-x 
Schutte, N. S., Searle, T., Meade, S., \& Dark, N. A. (2012). The Effect of Meaningfulness and Integrative Processing in Expressive Writing on Positive and Negative Affect and Life Satisfaction. Cognition and Emotion, 26(1), $144-152$. https://doi.org/10.1080/02699931.2011.562881

Wahyuni, E. N. (2012). Keefektifan Pendekatan Cognitive Behavior Modification untuk Meningkatkan Kemampuan Mengelola Marah pada Remaja. Disertasi tidak diterbitkan. Universitas Negeri Malang, Malang. 